\title{
Acute exposure to wood smoke from incomplete combustion - indications of cytotoxicity
}

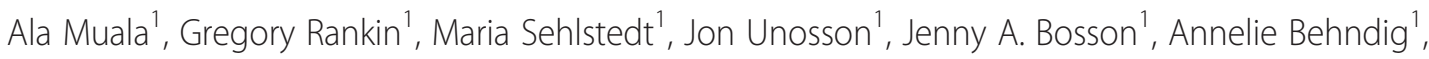 \\ Jamshid Pourazar', Robin Nyström², Esbjörn Pettersson², Christoffer Bergvall ${ }^{3}$, Roger Westerholm³ ${ }^{3}$ Pasi I. Jalava ${ }^{4}$, \\ Mikko S. Happo ${ }^{4}$, Oskari Uski ${ }^{4}$, Maija-Riitta Hirvonen ${ }^{4}$, Frank J. Kelly ${ }^{5}$, lan S. Mudway ${ }^{5}$, Anders Blomberg ${ }^{1}$, \\ Christoffer Boman ${ }^{2}$ and Thomas Sandström ${ }^{1^{*}}$
}

\begin{abstract}
Background: Smoke from combustion of biomass fuels is a major risk factor for respiratory disease, but the underlying mechanisms are poorly understood. The aim of this study was to determine whether exposure to wood smoke from incomplete combustion would elicit airway inflammation in humans.

Methods: Fourteen healthy subjects underwent controlled exposures on two separate occasions to filtered air and wood smoke from incomplete combustion with $\mathrm{PM}_{1}$ concentration at $314 \mu \mathrm{g} / \mathrm{m}^{3}$ for $3 \mathrm{~h}$ in a chamber. Bronchoscopy with bronchial wash (BW), bronchoalveolar lavage (BAL) and endobronchial mucosal biopsies was performed after $24 \mathrm{~h}$. Differential cell counts and soluble components were analyzed, with biopsies stained for inflammatory markers using immunohistochemistry. In parallel experiments, the toxicity of the particulate matter (PM) generated during the chamber exposures was investigated in vitro using the RAW264.7 macrophage cell line.

Results: Significant reductions in macrophage, neutrophil and lymphocyte numbers were observed in BW ( $p<0.01$, $<0.05,<0.05$, respectively) following the wood smoke exposure, with a reduction in lymphocytes numbers in BAL fluid $(<0.01$. This unexpected cellular response was accompanied by decreased levels of sICAM-1, MPO and MMP-9 ( $p<0.05$, $<0.05$ and $<0.01)$. In contrast, significant increases in submucosal and epithelial CD3+ cells, epithelial CD8+ cells and submucosal mast cells ( $p<0.01,<0.05,<0.05$ and $<0.05$, respectively), were observed after wood smoke exposure. The in vitro data demonstrated that wood smoke particles generated under these incomplete combustion conditions induced cell death and DNA damage, with only minor inflammatory responses.
\end{abstract}

Conclusions: Short-term exposure to sooty PAH rich wood smoke did not induce an acute neutrophilic inflammation, a classic hallmark of air pollution exposure in humans. While minor proinflammatory lymphocytic and mast cells effects were observed in the bronchial biopsies, significant reductions in BW and BAL cells and soluble components were noted. This unexpected observation, combined with the in vitro data, suggests that wood smoke particles from incomplete combustion could be potentially cytotoxic. Additional research is required to establish the mechanism of this dramatic reduction in airway leukocytes and to clarify how this acute response contributes to the adverse health effects attributed to wood smoke exposure.

Trial registration: NCT01488500

Keywords: Air pollution, Biomass, Bronchoscopy, Cytotoxicity, Neutrophils, Lymphocytes, Mast cells

\footnotetext{
* Correspondence: thomas.sandstrom@lung.umu.se

${ }^{1}$ Department of Public Health and Clinical Medicine, Division of Medicine/

Respiratory Medicine, Umeå University, Umeå, Sweden

Full list of author information is available at the end of the article
} 


\section{Background}

It is well known that exposure to ambient air pollution is associated with increased respiratory and cardiovascular morbidity and mortality [1]. While most focus has been on traffic-related air pollution, less attention has been directed towards the impact of smoke from biomass combustion. Source apportionment studies have shown that wood smoke from small-scale combustion for residential heating during winter is a major contributor to $\mathrm{PM}_{2.5}$ concentrations in ambient air in large cities around the world [2], with contributions in some European countries (i.e., Sweden, Finland, Germany and Austria) of between 15 and $25 \%$ [3].

Globally, more than 2.4 billion people are estimated to depend on biomass, such as wood, animal dung and crop residues, as a major source of energy for heating and cooking [4]. Furthermore, indoor air pollution has been rated as the third leading risk factor for global disease burden and WHO estimate that exposure to biomass smoke contributed to 3.5 million premature deaths in 2010 [5]. Exposure to wood smoke has been linked to elevated asthma prevalence, increased asthma symptoms in children and adults, as well as higher hospital admissions due to asthma attacks [6-8]. The association between long-term indoor wood smoke exposure and the development and worsening of COPD has been shown to be strong in many epidemiological studies [9, $10]$ and the risk for COPD development has been estimated to be more than doubled for solid fuel smoke compared with smoke from other types of fuels [11]. Exposure to smoke from combustion of wood and other biomass fuels has also been shown to increase the risk for acute and chronic lower respiratory tract infections, including pneumonias and tuberculosis $[7,12,13]$.

The physical and chemical properties of wood smoke particles can differ substantially depending on the combustion conditions and fuel used and it is likely that the physicochemical properties of the smoke particles determine their toxicological properties and health effects [2].

Recently, a series of studies addressed the respiratory and systemic effects of wood smoke using a range of experimental exposures in human subjects. Barregård and colleagues reported varying responses from several wood smoke exposure campaigns. These include increased levels of exhaled malondialdehyde and urinary PGF2 $\alpha$, suggesting enhanced oxidative stress, and some indications of altered coagulability along with increased serum concentrations of club cell protein 16 (CC-16) and amyloid A [14-16]. Other studies have shown no proinflammatory effects in peripheral blood $[17,18]$. Ghio et al. reported increased percentages of neutrophils in blood, bronchial wash (BW) and bronchoalveolar lavage (BAL) after exposure to smoldering hardwood [19], We have previously demonstrated a mild oxidative response in
BAL fluid, but with no changes in BW or BAL cell numbers in human subjects after experimental exposure to smoke from "low-temperature" incomplete softwood pellet combustion, where the particulate matter PM was dominated by organic matter [20]. In a recent paper [21], based on the same exposure scenario and study population as in the present paper, we investigated the effects of incomplete combustion of birch wood logs, resulting in a sooty polycyclic aromatic hydrocarbon (PAH) rich smoke, representing commonly occurring exposures with chimney stoves. The results from this study confirmed that wood smoke may indeed cause acute cardiovascular effects, demonstrated by increased arterial stiffness, together with reduction in heart rate variability (HRV), which in population-based studies have been strongly linked with adverse health effects [21-23].

The aim of the current study was to further characterize the respiratory effects of exposure to wood smoke from incomplete soot-rich combustion in a typical wood stove. Studies using bronchial mucosal biopsies have previously provided detailed information on the associations between the upregulation of redox-sensitive signaling pathways and the induction of an acute neutrophilic response following diesel exhaust exposure [24-26]. The hypothesis addressed in the present study was that exposure to wood smoke, generated during incomplete combustion conditions, would elicit a similar acute inflammatory response in the airways, as shown after diesel engine exhaust exposure.

Due to the designed differences in combustion conditions, the incomplete combustion scenario, as used in the present and companion paper [21], differs from the previously investigated exposure situation [20], as regards to the properties of the PM emissions. The previously studied wood smoke [20] was generated from softwood pellets during adjusted low-temperature conditions in the burner, with the PM dominated by organic matter (pyrolysis products), whereas the presently used smoke was generated from controlled wood log combustion in a stove under partly incomplete high-burn rate conditions, thus expecting periods of high soot and PAH generation.

\section{Results}

\section{Wood smoke characterization}

The average total $\mathrm{PM}_{1}$ concentration in the chamber during the exposures, measured by a TEOM, was $314 \mu \mathrm{g} / \mathrm{m}^{3}$ (range $232-356 \mu \mathrm{g} / \mathrm{m}^{3}$ ), which was associated with average $\mathrm{NO}_{\mathrm{x}}$ and $\mathrm{CO}$ concentrations of $0.41 \mathrm{ppm}$ and $25 \mathrm{ppm}$, respectively. Due to the combustion procedure, as described in materials and methods, the concentration of PM and gases in the chamber did vary, although the aerosol residence time in the chamber ( 20 min) largely compensated for this. During a typical exposure period, the total particle number concentration 
in the chamber varied between 1 and $2.5 \times 10^{5}$ particles/ $\mathrm{cm}^{3}$. The particle number size distribution was bimodal with one peak at $60-70 \mathrm{~nm}$ and one peak at $150-200 \mathrm{~nm}$. Previous studies indicate that the $60-70 \mathrm{~nm}$ peak consist of alkali salt particles (e.g., $\mathrm{K}_{2} \mathrm{SO}_{4}$ and $\mathrm{KCl}$ ) and the 150-200 nm peak consists of a soot mode with condensed organic material $[27,28]$.

The total carbonaceous (TC) PM of the wood smoke was dominated by elemental carbon (EC) and the PM consisted of $38 \%$ soot, $24 \%$ organics and the remainder of ash forming elements (Additional file 1: Table S1 and Additional file 2: Table S2). It is notable that the TC measurements were not done exactly in parallel with the DGI collections, as they demanded different collection times. Thus, exact mass closure is not possible to calculate. The total PAH concentration in the chamber was $1053 \pm 648 \mathrm{ng} / \mathrm{m}^{3}$, of which $74 \%\left(775 \mathrm{ng} / \mathrm{m}^{3}\right)$ was in the particulate phase, see Table 1 . The 12 dominating $\mathrm{PAH}$ compounds in the PM fraction, accounting for $86 \pm 2 \%$ of the total analyzed PAH, were (in descending order); benzo(a)pyrene, benzo(b)fluoranthene, benz(a)anthracene, benzo(e)pyrene, benzo(ghi)perylene, indeno(1,2,3-cd)pyrene, benzo(ghi)fluoranthene, benzo (k)fluoranthene, coronene, pyrene, fluoranthene and perylene. In contrast to diesel exhaust particulates, high molecular weight PAHs ( $\geq 228 \mathrm{Da})$ dominate the PAH profile ( $85 \%$ in average) of the wood smoke particulate matter. This is expected as the PAHs are purely of pyrogenic origin [29]. The concentrations of all analyzed PAH compounds are given in Additional file 1: Table S1.

\section{Immunohistochemistry of the bronchial biopsies}

Representative bronchial biopsies were obtained from all 14 subjects after both air and wood smoke exposure. There was a significant increase in submucosal and epithelial CD3+ lymphocytes $(p<0.01$ and $<0.05$ respectively), together with $\mathrm{CD} 8+$ lymphocytes in the epithelium $(p<0.05)$ after exposure to wood smoke compared to filtered air (Fig. 1). CD4+ lymphocytes were not significantly affected by exposures. Mast cells were increased in

Table 1 Exposure characteristics

\begin{tabular}{lll}
\hline & Unit & Mean $\pm \mathrm{SD}$ \\
\hline $\mathrm{PM}_{1}$ mass conc. (TEOM) & $\mu \mathrm{g} / \mathrm{m}^{3}$ & $314 \pm 38$ \\
$\mathrm{PM}_{1}$ mass conc. (filter) & $\mu \mathrm{g} / \mathrm{m}^{3}$ & $294 \pm 36$ \\
$\mathrm{CO}$ & $\mathrm{ppm}$ & $25 \pm 6$ \\
$\mathrm{NOx}$ & $\mathrm{ppm}$ & $0.41 \pm 0.12$ \\
EC/TC (elemental/total carbon) & & $0.72 \pm 0.08$ \\
Organic fraction of total PM & $\%$ & $24 \pm 8$ \\
Soot fraction of total $\mathrm{PM}_{1}$ & $\%$ & $38 \pm 9.9$ \\
PAH-PM associated & $\mu \mathrm{g} / \mathrm{m}^{3}$ & $0.78 \pm 0.56$ \\
PAH-semi-volatile & $\mu \mathrm{g} / \mathrm{m}^{3}$ & $0.28 \pm 0.12$ \\
\hline
\end{tabular}

the submucosa $(p<0.05)$ after wood smoke exposure (Fig. 1). There were no significant changes in other cell types or adhesion molecule expression after exposure to wood smoke (Additional file 3: Figures S1 and Additional file 4: Figure S2).

\section{Bronchial wash and bronchoalveolar lavage}

Statistically significant reductions of macrophages, neutrophils and lymphocytes were found in the bronchial wash (BW) $(p<0.05-<0.01$, Table 2 and Additional file 5: Figure S3) after wood smoke exposure compared to filtered air. Moreover, wood smoke exposure significantly reduced the BW levels of soluble Intercellular Adhesion Molecule-1 (sICAM-1), myeloperoxidase (MPO) and matrix metallopeptidase 9 (MMP-9) $(p<0.05-<0.01$ (Table 3, Additional file 6: Figure S4). The reductions in neutrophils and decreases in MPO and MMP-9 after wood smoke exposure were strongly correlated, as shown in Fig. $2(p<0.01$, $r=0.791$ and $p<0.01, r=0.70$, respectively).

Baseline BW neutrophil values differed slightly from some preceding studies, confirming the importance of internal controls in this kind of study, where every subjects served as his or her control with air and wood smoke exposure in blinded random order.

Due to the significant reduction in cell numbers, markers of cell death (LDH and HMBGP1 as markers of necrosis and active caspase 3 as a marker of apoptosis) were analysed in the BW supernatant. LDH levels were significantly lower after wood smoke exposure compared to filtered air $(p<0.05)$, whereas HMBGP1 levels remained unchanged. The levels of active caspase 3 were below the limits of detection.

In bronchoalveolar lavage (BAL), wood smoke exposure resulted in a significant decrease in the total lymphocyte numbers (Table 2) as well as the total number of $\mathrm{CD} 3+$, $\mathrm{CD} 4+, \mathrm{CD} 8+, \mathrm{CD} 4+\mathrm{HLADR}+, \mathrm{CD} 8+\mathrm{CD} 314+, \mathrm{CD} 4+$ CD25+ cells $(p<0.05-0.01)$ Table 4, Additional file 7 : Figure S5). In contrast, BAL IL-6, sICAM-1, CC16, GrzA, MPO and MMP-9 concentrations were unaffected by the exposures (Table 3). There was a significant increase in total glutathione (GSx) in BAL after exposure to wood smoke $(p<0.02)$, with a trend towards increased reduced glutathione (GSH), $(p=0.06)$ but concentrations of glutathione disulphide (GSSG) remained unchanged (Table 3).

\section{Peripheral blood}

Flow cytometry analyses on peripheral blood demonstrated wood smoke exposure led to significant increases in CD16+CD56+ cells as well as CD4+HLADR+ and CD8+HLADR+ cells $(p<0.05-0.01$, Table 5$)$, while other cell types were unchanged. No significant changes were seen for IL6, TNF- $\alpha$, sICAM-1 and CC16 between exposures. (Additional file 8: Table S3). 


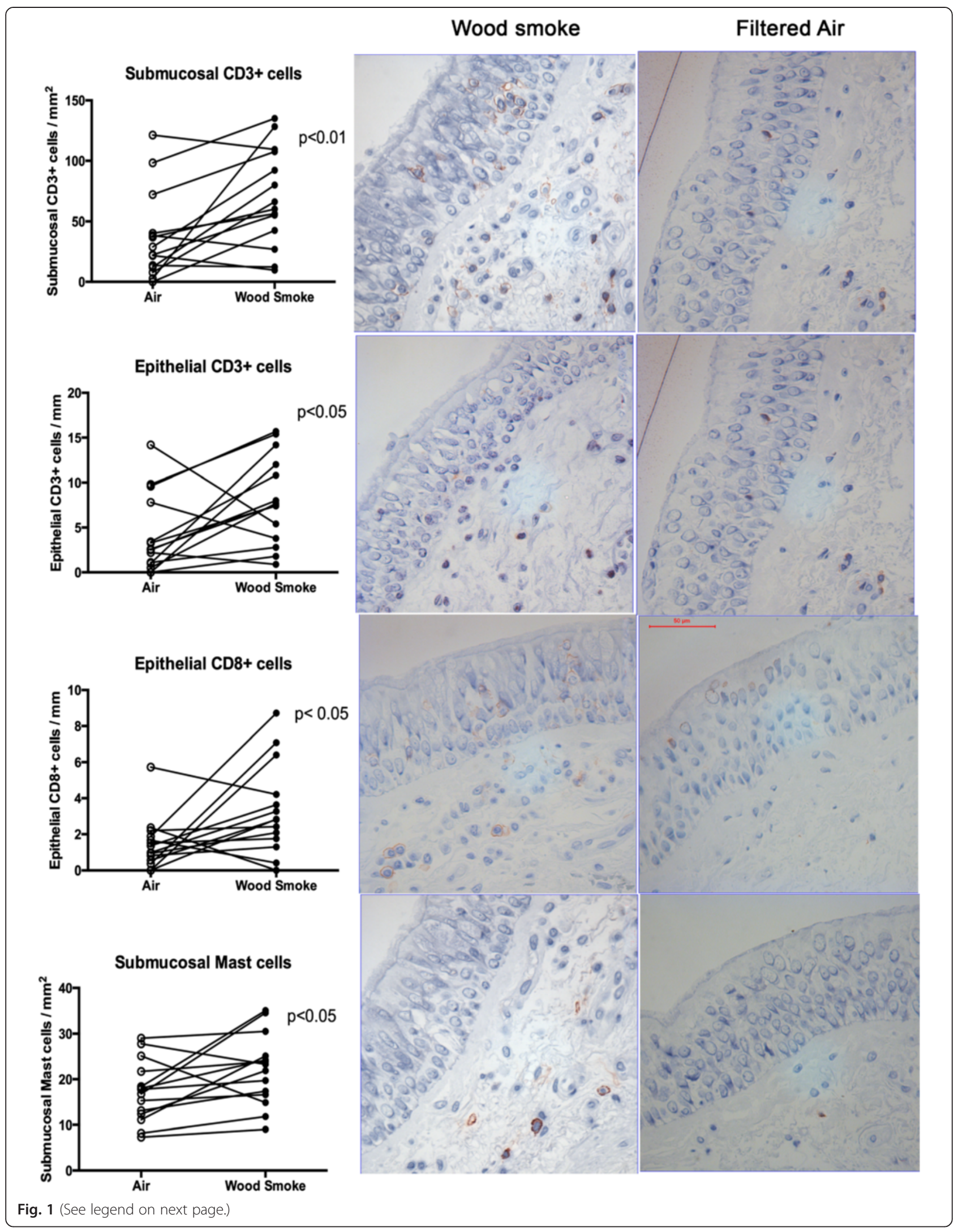


(See figure on previous page.)

Fig. 1 Immunohistochemical staining of bronchial mucosal biopsies. All photos have been taken at the same magnification ( $\times 40)$. Bar represents $50 \mu \mathrm{m}$. in order from the top and downwards the four panels demonstrate: a/ A significant increase in submucosal and b/ epithelial CD3+ lymphocytes $(p<0.01$ and $<0.05$ respectively), together with $c / C D 8+$ cells in the epithelium $(p<0.05)$ after exposure to wood smoke vs. filtered air. Panel $d /$ displays that mast cells were significantly increased in the submucosa $(p<0.05)$ after wood smoke exposure. There was no neutrophilic infiltration in the bronchial biopsies (data not shown)

\section{Lung function test}

Lung function parameters were not significantly changed by wood smoke compared with filtered air exposures. (Additional file 9: Table S4).

\section{$\mathrm{FE}_{\mathrm{NO}}$}

There were no significant differences between changes in $\mathrm{FE}_{\mathrm{NO}}$ after exposure to wood smoke vs. air. (Additional file 10: Table S5).

\section{Wood combustion PM induced in vitro toxicity}

A concentration-dependent and statistically significant decrease in cellular metabolic activity (MTT, Fig. 3a) and viability (PI, Fig. 3b) was observed after exposure of mouse macrophages to $\mathrm{PM}_{1}$ samples from wood log combustion. In contrast, a significant and concentrationdependent increase in the number of subG1 cells was detected in cell cycle analysis (Fig. $3 \mathrm{c}$ and Additional file 11: Figure S6A and S6B). Moreover, a concentrationdependent and statistically significant increase in DNA damage was detected when compared to control cells (Fig. 3d). Only a minor PM-induced MIP-2 response was detected in the macrophage cell line, whereas TNF- $\alpha$ concentrations remained at the control level (Additional file 12: Figure S7).

\section{Discussion}

In this study, we examined the pulmonary responses in human subjects exposed to wood smoke from a chimney stove resembling real-world combustion conditions. Under these controlled incomplete combustion conditions, particles were dominated by soot and organic matter. This exposure differed from a previous exposure to wood smoke from incomplete combustion of softwood pellets, as regards to a higher soot fraction and particulate PAH. Overall, the wood smoke in the present study was produced under different fuel, appliance and controlled combustion conditions, that resulted in PM with clearly different chemical properties than the PM in the previous study by Sehlstedt et al. [20]. Based on our observations from previous chamber challenge studies with diesel exhaust, ozone and tobacco smoke, we hypothesized that wood smoke would elicit an acute neutrophilic infiltration of the bronchial tissue [24, 30-33].

Contrary to our hypothesis, we found no evidence of neutrophilic infiltration into the bronchial mucosa, BW or BAL. The lavage fluid response also differed from other experimental air pollution exposure studies, in terms of a decrease in recovered inflammatory cells and soluble components. The basis for the decrease in airway leukocytes remains oblique, but was not associated with an increase in markers indicative of cellular necrosis, apoptosis (LDH, HMBGP1 and active caspase 3) or overt oxidative stress (GSSG). The later result was in agreement with our preceding human exposure study using smoke from a pellet burner [20].

The decrease in the number of airway leukocytes after wood smoke, predominately macrophages, is significant in light of their role in innate immune defense, particularly the clearance of inhaled PM. The reduction in

Table 2 Bronchial wash and bronchoalveolar lavage cell data from experimental exposure of 13 healthy subjects to filtered air and wood smoke. Data are given as medians with interquartile range

\begin{tabular}{|c|c|c|c|c|c|c|}
\hline \multirow[t]{2}{*}{ Cells $10^{4} / \mathrm{ml}$} & \multicolumn{2}{|l|}{ BW } & \multirow{2}{*}{$\begin{array}{l}\text { P-value } \\
\text { Air vs. Wood smoke }\end{array}$} & \multicolumn{2}{|l|}{ BAL } & \multirow{2}{*}{$\begin{array}{l}\text { P-value } \\
\text { Air vs. Wood smoke }\end{array}$} \\
\hline & Air & Wood smoke & & Air & Wood smoke & \\
\hline \multirow[t]{2}{*}{ Macrophages } & 6.1 & 3.95 & 0.009 & 8.50 & 9.25 & 0.60 \\
\hline & $4.48-12.56$ & $2.60-6.07$ & & $8.21-10.05$ & $7.31-12.07$ & \\
\hline \multirow[t]{2}{*}{ Neutrophils } & 3.05 & 1.19 & 0.046 & 0.21 & 0.15 & 0.861 \\
\hline & $2.42-6.18$ & $0.76-2.72$ & & $0.11-0.38$ & $0.05-0.41$ & \\
\hline \multirow[t]{2}{*}{ Lymphocytes } & 0.45 & 0.26 & 0.023 & 2.09 & 1.62 & 0.004 \\
\hline & $0.21-0.98$ & $0.07-0.31$ & & $1.39-2.89$ & $1.16-1.97$ & \\
\hline \multirow[t]{2}{*}{ Mast cells } & 0.009 & 0.0046 & 0.061 & 0.0047 & 0.01 & 0.82 \\
\hline & $0.002-0.29$ & $0.0018-0.0089$ & & $0.00-0.024$ & $0.0024-0.016$ & \\
\hline \multirow[t]{2}{*}{ Eosinophils } & 0.00 & 0.00 & 0.345 & 0.00 & 0.01 & 0.441 \\
\hline & $0.00-0.01$ & $0.00-0.2$ & & $0.00-0.01$ & $0.00-0.03$ & \\
\hline
\end{tabular}


Table 3 Soluble components in bronchial wash and bronchoalveolar lavage from experimental exposure of 13 healthy subjects to filtered air and wood smoke. Data are given as medians with interquartile range

\begin{tabular}{|c|c|c|c|c|c|c|}
\hline \multirow{2}{*}{$\begin{array}{l}\text { Inflammatory } \\
\text { markers }\end{array}$} & \multicolumn{2}{|l|}{ BW } & \multirow{2}{*}{$\begin{array}{l}\text { P-value } \\
\text { Air vs. Wood smoke }\end{array}$} & \multicolumn{2}{|l|}{ BAL } & \multirow{2}{*}{$\begin{array}{l}\text { P-value } \\
\text { Air vs. Wood smoke }\end{array}$} \\
\hline & Air & Wood smoke & & Air & Wood smoke & \\
\hline \multirow[t]{2}{*}{ IL6 pg/ml } & 4.08 & 3.96 & 0.646 & 1.13 & 1.61 & 0.515 \\
\hline & $2.25-7.25$ & $3.14-5.87$ & & $0.79-1.91$ & $0.73-2.15$ & \\
\hline \multirow[t]{2}{*}{ slCAM-1 ng/ml } & 35.20 & 18.30 & 0.028 & 100.45 & 98.10 & 0.878 \\
\hline & $18.75-45.87$ & $16.72-26.90$ & & $53.10-163.22$ & $67.52-126.00$ & \\
\hline \multirow[t]{2}{*}{ CC16 ng/ml } & 582.70 & 566.60 & 0.239 & 328.80 & 382.60 & 0.196 \\
\hline & $542.45-724.75$ & $556.45-616.10$ & & $298.15-438.00$ & $313.05-488.50$ & \\
\hline \multirow[t]{2}{*}{ GrzA pg/ml } & 346.00 & 242.50 & 0.221 & 149.60 & 113.60 & 0.753 \\
\hline & $178.65-661.95$ & $197.20-266.15$ & & $45.35-232.80$ & $62.30-197.20$ & \\
\hline \multirow[t]{2}{*}{ MPO ng/ml } & 26.50 & 17.80 & 0.019 & 2.40 & 2.10 & 0.666 \\
\hline & $8.05-70.10$ & $8.30-32.65$ & & $0.90-5.60$ & $1.05-3.40$ & \\
\hline \multirow[t]{2}{*}{ MMP9 ng/ml } & 13.40 & 6.60 & 0.006 & 0.50 & 0.70 & 0.726 \\
\hline & $5.55-30.05$ & $3.65-11.20$ & & $0.40-1.95$ & $0.20-1.90$ & \\
\hline \multirow[t]{2}{*}{ GSx $\mu \mathrm{mol} / \mathrm{L}$} & 0.88 & 0.94 & 0.133 & 0.63 & 0.99 & 0.013 \\
\hline & $0.42-1.20$ & $0.58-2.75$ & & $0.47-1.02$ & $0.58-1.48$ & \\
\hline \multirow[t]{2}{*}{$\mathrm{GSH} \mu \mathrm{mol} / \mathrm{L}$} & 0.58 & 0.65 & 0.173 & 0.49 & 0.73 & 0.064 \\
\hline & $0.32-0.95$ & $0.41-2.33$ & & $0.27-0.81$ & $0.48-1.13$ & \\
\hline \multirow[t]{2}{*}{ GSSG $\mu \mathrm{mol} / \mathrm{L}$} & 0.10 & 0.21 & 0.279 & 0.04 & 0.04 & 0.196 \\
\hline & $0.02-0.19$ & $0.05-0.23$ & & $0.00-0.13$ & $0.02-0.22$ & \\
\hline
\end{tabular}

airway leukocytes accompanied with the parallel reduction of the secreted component could potentially increase the susceptibility to airway infections. Indeed, exposure to wood smoke and other biomass smoke has been associated with acute and chronic respiratory infections, including tuberculosis [34, 35]. A meta-analysis of 24 studies demonstrated a two-fold increased risk of pneumonia associated with biomass exposure [13]. Moreover, exposure to wood smoke has been associated with increased mortality by respiratory infections in children $[12,36]$.
To further clarify this unexpected result, we exposed a macrophage cell line to the wood smoke $\mathrm{PM}_{1}$ generated in these exposures, demonstrating a loss of cell viability (mitochondrial activity assessed using the MTT assay) and an increase in DNA damage (dose-dependent OTM response measured by comet assay), associated with a trivial inflammatory response. However, at the highest PM doses (150 and $300 \mu \mathrm{g} \mathrm{ml}^{-1}$ ) decreased cell viability was detected and thus, the measured OTM value could potentially be due to cell death, rather than PM induced

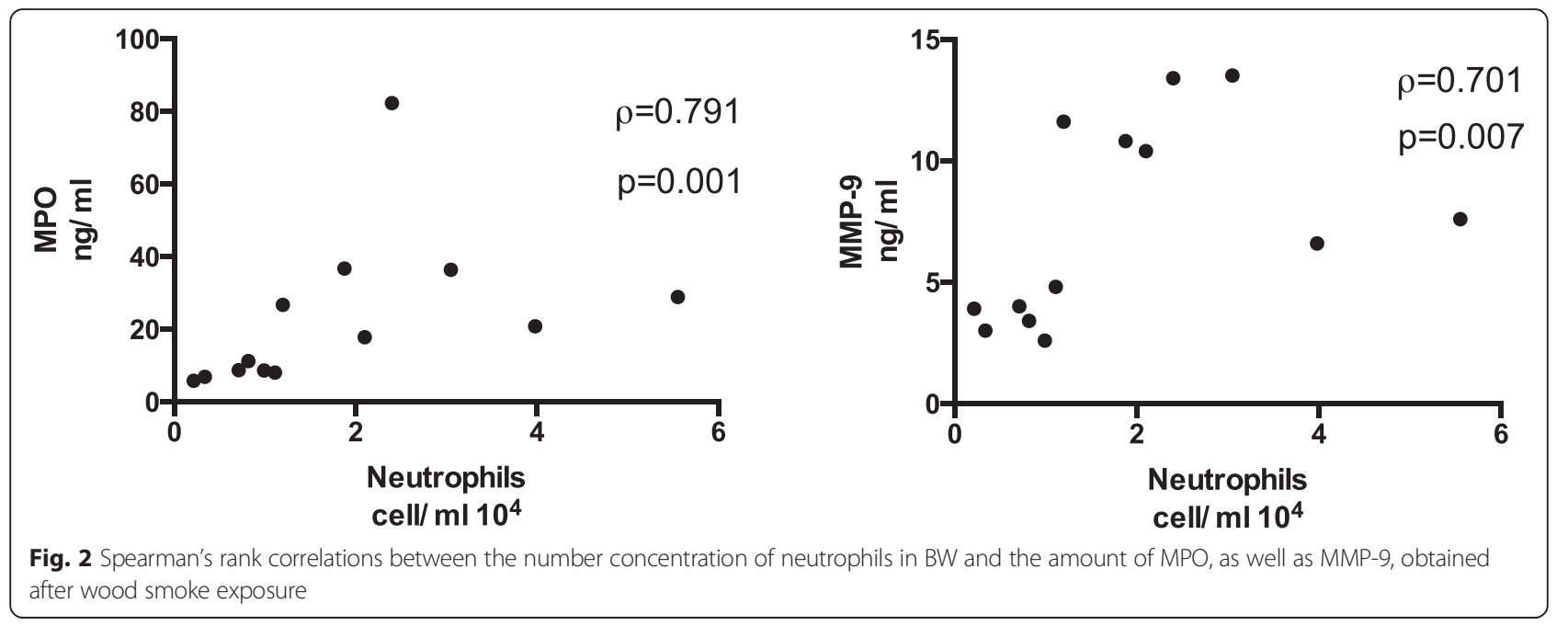


Table 4 Flow cytometry data on lymphocyte subsets in bronchoalveolar lavage from experimental exposure of 13 healthy subjects to filtered air and wood smoke. Data are given as medians with interquartile range

\begin{tabular}{lllc}
\hline & $\begin{array}{l}\text { Filtered } \\
\text { air }\end{array}$ & $\begin{array}{l}\text { Wood } \\
\text { smoke }\end{array}$ & $\begin{array}{l}\text { P-value } \\
\text { Air vs. Wood smoke }\end{array}$ \\
\hline $\mathrm{CD} 3+\times 10^{4} / \mathrm{ml}$ & 1.80 & 1.25 & 0.006 \\
$\mathrm{CD} 4+\times 10^{4} / \mathrm{ml}$ & $1.17-1.34$ & $0.98-1.75$ & \\
& $0.78-1.34$ & 0.74 & 0.006 \\
$\mathrm{CD} 8+\times 10^{4} / \mathrm{ml}$ & 0.60 & 0.47 & \\
& $0.37-0.94$ & $0.24-0.75$ & 0.013 \\
$\mathrm{CD} 16+\mathrm{CD} 56+\times 10^{3} / \mathrm{ml}$ & 0.57 & 0.55 & 0.055 \\
& $0.49-1.18$ & $0.36-0.64$ & \\
$\mathrm{CD} 4+\mathrm{CD} 25+\times 10^{3} / \mathrm{ml}$ & 0.9 & 0.68 & 0.016 \\
& $0.77-1.41$ & $0.58-0.97$ & \\
$\mathrm{CD} 4+\mathrm{HLADR}+\times 10^{3} / \mathrm{ml}$ & 1.44 & 1.16 & 0.023 \\
& $0.96-2.89$ & $0.67-1.81$ & \\
$\mathrm{CD} 8+\mathrm{HLADR}+\times 10^{3} / \mathrm{ml}$ & 1.48 & 1.07 & 0.087 \\
& $0.63-1.82$ & $0.37-1.68$ & \\
$\mathrm{CD} 8+\mathrm{CD} 314+\times 10^{3} / \mathrm{ml}$ & 2.15 & 1.32 & 0.033 \\
& $1.18-3.17$ & $0.73-2.56$ & \\
\hline
\end{tabular}

genotoxicity. The macrophage cell line was chosen because the immunological cell response in the lungs demanded further clarification. The RAW 264.7 cells are widely used in air pollution studies as a model for macrophage responses, despite their mouse origin as primary human macrophages are cumbersome to obtain for these kinds of studies. A benefit apart from availability is that

Table 5 Flow cytometry data of peripheral blood lymphocyte subsets after exposure to filtered air and wood smoke in 14 healthy subjects. Data are given as medians with interquartile ranges

\begin{tabular}{llll}
\hline Cell $\times 10^{6} / \mathrm{ml}$ & $\begin{array}{l}\text { Filtered } \\
\text { air }\end{array}$ & $\begin{array}{l}\text { Wood } \\
\text { smoke }\end{array}$ & $\begin{array}{l}\text { Filtered air vs. wood smoke } \\
\text { p-value }\end{array}$ \\
\hline CD3+ & 1.39 & 1.43 & 0.064 \\
& $1.12-1.98$ & $1.19-2.38$ & \\
CD4+ & 0.78 & 0.89 & 0.140 \\
& $0.67-1.16$ & $0.60-1.21$ & \\
CD8+ & 0.50 & 0.55 & 0.140 \\
& $0.35-0.73$ & $0.40-0.83$ & \\
CD3-CD16+CD56+ & 0.12 & 0.17 & 0.026 \\
& $0.09-0.20$. & $0.13-0.25$ & \\
CD4+HLADR+ & 0.03 & 0.04 & 0.004 \\
& $0.02-0.05$ & $0.03-0.05$ & \\
CD8+HLADR+ & 0.08 & 0.09 & 0.009 \\
& $0.04-0.14$ & $0.05-0.17$ & \\
\hline
\end{tabular}

RAW 264.7 results can be compared to wide database of previous results, from our lab and others. Moreover, macrophages are a relevant model for unraveling the mechanisms induced by air pollution exposure. The cell line is not aimed for direct interpolation of the results to humans, but rather for revealing the mechanisms of toxicity. Therefore, rather large particle doses were used compared to human exposures in order to generate the differences in toxic responses between wood combustion PM and blank substrate exposures.

The results from the cell exposures are in agreement with other in vitro and in vivo (animal) studies with wood combustion-derived particles, in which the PAHrich particles have been shown to induce decreased cell metabolic activity and viability [37-39], with an absence of a pronounced inflammatory response [40-42]. Moreover, significant DNA damage in vitro has been associated with the organic carbon (OC) content of PM samples [43-45]. Thus the absence of an overt neutrophilia in the human exposure study might be related to a decreased release of pro-inflammatory mediators due the loss, or impaired function of airway phagocytic cells.

The observation that wood smoke exposure did not elicit an airway neutrophilia was unexpected, however, we cannot totally exclude the possibility that a transient neutrophilic influx occurred earlier than the examined time point. Based on previous studies with other air pollutants, this appears unlikely, especially as no increases in MPO or MMP-9 were found. Ghio et al. reported an increase in the percentage of neutrophils in BW and BAL fluid after a 2-hour exposure of healthy subjects to wood smoke with a particle mass concentration of $500 \mu \mathrm{g} / \mathrm{m}^{3}$, generated from smoldering red oak wood heated on an electric heating element. It is unclear, however, whether the reported airway neutrophilia was due to shifts in the percentages of other inflammatory cell types or whether there was a real expansion in neutrophil numbers [19].

While we observed no evidence of neutrophil influx into the airways post wood smoke exposure, a lymphocytic infiltration of CD8+ cells was found in the bronchial epithelium, together with CD3+ cells and mast cell infiltration in the bronchial mucosa. Again, the increase in cytotoxic CD8+ cells within the epithelium without any significant $\mathrm{CD} 4+$ cell infiltration differs from the airway inflammatory cell responses previously observed following exposure to diesel exhaust [24] and tobacco smoke [46].

Mast cell recruitment into the bronchial mucosa has been a common finding after air pollution exposures in human subjects [47-50]. Several earlier studies, which employed BAL alone to evaluate lung responses, reported increased mast cell recovery from the peripheral airspaces after exposure to $\mathrm{SO}_{2}$ and $\mathrm{NO}_{2}[51,52]$. 


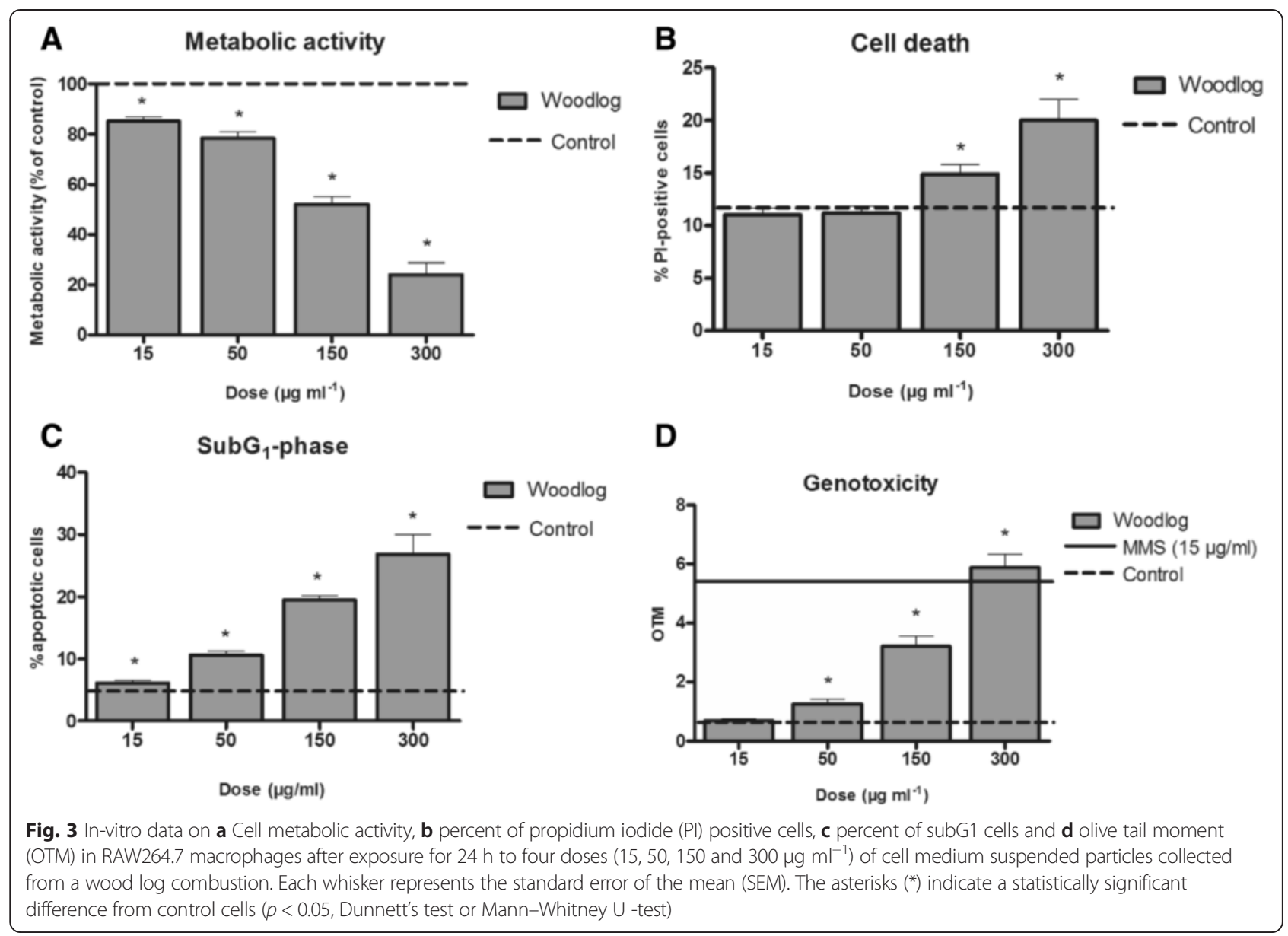

Mast cell infiltration in the bronchial mucosa may be present as early as $6 \mathrm{~h}$ after exposure to diesel exhaust and $\mathrm{O}_{3}$, and as early as $4 \mathrm{~h}$ after $\mathrm{SO}_{2}$ and $\mathrm{NO}_{2}$. We interpret this as a rapid systemic response, as these cells are released from the bone marrow following stimuli by factors such as stem cell factor, TGF-beta and fractalkine. Particulate matter may induce rapid systemic effects and other not yet identified signals that result in mast cell recruitment from the bone marrow.

Mast cells are often considered in allergy and IgEmediated reactions but may also be involved in many other immune responses. In the lungs, mast cells have for instance been shown to be present in tissue damage situations and there is debate whether they are mainly involved in enhancing damage or in the restoration phase [53]. It appears that mast cells have capability for both. The mast cell pro-inflammatory potential to release cytokines, histamine and proteases is well known and they may orchestrate inflammatory cascades and cell recruitment. Mast cells may also be important in the response to cell injury by several pathways including IL-33 secreted by damaged or necrotic cells [54].
With regard to the systemic effects of wood smoke exposure, we have recently reported from the present exposure study that inhalation of the investigated sooty wood smoke caused an immediate increase in central arterial stiffness with reduced heart rate variability [21]. This type of response has been associated with adverse long-term outcome in regards to morbidity and mortality $[22,55,56]$. This cardiovascular response occurred in the absence of overt systemic neutrophilia, or increase in circulating pro-inflammatory mediators. This is in line with observations from earlier humans challenge studies using various types of wood smoke, which failed to show increased levels of IL-6 and TNF-alpha, with only minor or no indications of oxidative stress and DNA-damage $[17,18]$. We did observe a 1.5 fold increase in blood CD16/CD56 NK cells and increased expression of the activation marker HLA-DR on CD4 and CD8 cells. This was consistent with findings by Dutta and coworkers in India, who used flow cytometry to determine immune markers in blood of women exposed to biomass smoke. These investigators also reported changes in CD4, CD8 and CD19 cells, in 
contrast to our data, which may be related to alterations in systemic immunity by long-term biomass exposure [57]. This is supported by results from a cross sectional study in which, wood smoke exposure caused high gene expression of mediators linked to airway inflammation and remodeling [58].

\section{Conclusions}

Short-term exposure to soot- and PAH-rich wood smoke did not induce a neutrophilic airway inflammation, which has been a hallmark of acute air pollution exposures in humans. While the current study demonstrated only minor proinflammatory lymphocytic and mast cell effects in the bronchial biopsies, there were unexpected reductions in BW and BAL cell numbers and soluble inflammatory markers. These findings are supported, in part, by in vitro data from the present and other studies which indicate that PAH-rich wood smoke particles from incomplete combustion have the capacity to cause cellular dysfunction and DNA damage. Further research is needed to determine the precise role of these events in relationship to the adverse health effects attributed to wood smoke exposure.

\section{Methods}

\section{Subjects}

Fourteen healthy volunteers (mean age 26, range 21-35 year, 8 males, 6 females, all never smokers) were included. All subjects underwent a physical examination, baseline blood count and renal function assessment, spirometry $\left(\mathrm{FEV}_{1}, \mathrm{VC}\right.$ and $\left.\mathrm{FEV}_{1} / \mathrm{VC}\right)$ and 12 lead electrocardiogram prior to inclusion. All were free of airway infection for at least 6 weeks prior to participation. The study was approved by the regional ethical review board and performed in accordance with the declaration of Helsinki. All subjects gave their written informed consent.

\section{Study design}

The study was performed in a randomized, double blind, crossover fashion with each subject being exposed on two occasions to air and wood smoke in an exposure chamber at Thermochemical Energy Conversion Laboratory at Umeå University. The chamber is made of stainless steel, has a volume of a $15 \mathrm{~m}^{3}$ and an air exchange rate of around three times per hour and has been previously described [21]. The mean PM concentration of wood smoke was $314 \mu \mathrm{g} / \mathrm{m}^{3}$. The exposures lasted for three hours, during which the subject performed intermittent exercise on a bicycle ergometer, alternate with rest at 15-minute intervals, to achieve an average minute ventilation of $20 \mathrm{~L} / \mathrm{min} / \mathrm{m}^{2}$ body surface. During the exposures, symptoms were recorded according to the modified Borg scale, as described previously [59].

\section{Wood smoke generation}

A common Nordic chimney wood stove was used to generate wood smoke under incomplete combustion conditions. Birch wood logs with a moisture content of $16-18 \%$ were inserted every 5-15 min to maintain a high burn rate with repeated air-starved conditions. The exposure conditions, measurements and characteristics have been described in detail in a companion paper in this journal, which reported on the cardiovascular effects of the same wood smoke exposure and subjects as in the present study [21].

$\mathrm{PM}_{1}$ samples, for the toxicological analyses in vitro, were collected on polytetrafluoroethylene (PTFE) substrates from the chamber exhaust air with a Dekati gravimetric impactor (DGI, Dekati Ltd., Finland). The handling of the sampling substrates prior and after collection is described earlier in detail by Jalava et al. 2012.

\section{Lung function test}

Lung function tests were performed before as well as 0 and $24 \mathrm{~h}$ after exposure (pre-bronchoscopy) using a spirometer (Jaeger MSC spirometer, Germany). The tests were performed according to the guidelines of the American Thoracic Society [60].

\section{Fraction of exhaled nitric oxide}

Fraction of exhaled nitric oxide (FeNO) at the flow rates of $50 \mathrm{ml} / \mathrm{s}$ and $10 \mathrm{ml} / \mathrm{s}$ were measured before as well as 0 and after $24 \mathrm{~h}$ after each exposure by using a chemiluminescence analyser (NiOX; Aerocrine AB, Stockholm, Sweden).

\section{Blood samples}

Blood samples were obtained at baseline, 24 and $44 \mathrm{~h}$ after exposure. The samples were centrifuged at $3,000 \times g$ for $30 \mathrm{~min}$ at $4{ }^{\circ} \mathrm{C}$ before plasma was removed and frozen at $-80{ }^{\circ} \mathrm{C}$ for further analysis. Plasma samples were analysed for markers of acute inflammation: Interleukin 6 (IL-6), tumor necrosis factor-alpha (TNF- $\alpha$ ), soluble Intercellular Adhesion Molecule-1 (sICAM-1) and club cell secretory protein 16 (CC16, formerly called clara cell protein 16) using DuoSet ELISA kits (R\&D Systems, Abingdon, UK), according to the manufacturer's instructions.

\section{Bronchoscopy}

Bronchoscopy was performed $24 \mathrm{~h}$ after each exposure using a flexible video bronchoscope (Olympus BF IT200, Tokyo, Japan), as previously described [24, 31]. The subjects received topical anesthesia with Lidocain in pharynx, epipharynx and within the bronchial tree. Bronchial wash (BW), $2 \times 20 \mathrm{ml}$, and bronchoalveolar lavage (BAL), $3 \times 60 \mathrm{ml}$, were collected. The obtained aspirates were collected in separate containers and placed in ice before being filtered through a nylon filter (pore diameter of 
$100 \mu \mathrm{m})$ and centrifuged at $400 \times g$ for $15 \mathrm{~min}$. Supernatants were frozen at $-80{ }^{\circ} \mathrm{C}$ for later analyses for; IL-6, club cell protein-16 (CC-16), Granzyme A (GrzA), soluble-intracellular adhesion molecule-1 (s-ICAM-1), matrix metallopeptidase 9 (MMP-9), myeloperoxidase (MPO) (R\&D Systems, Abingdon, UK), high-mobility group box protein 1 (HMGB1) (IBL International, Hamburg, Germany), human active-caspase 3 (Invitrogen, Camarillo, USA), and lactate dehydrogenase (LDH) (Roche, Basel, Switzerland), performed according to the manufacturer's instructions. Endobronchial mucosal biopsies were taken either from the anterior part of the main carina and the subcarinae of the third and fourth generation airway of the right side or from the posterior part of the main carina and the subcarinae on the left side. The order of left/right bronchial biopsy sampling was randomized, with contralateral biopsies taken at the second bronchoscopy.

\section{Immunohistochemical analysis}

Endobronchial mucosal biopsies obtained during bronchoscopy were processed and embedded in glycol methacrylate resin (Polyscience; Northampton, England), as previously described [24]. $2 \mu \mathrm{m}$ thick sections were cut and immunostained with monoclonal mouse antibodies for the following markers: Neutrophil elastase; mast cell tryptase (Dako); CD3 (Biolegend); CD4 (Biolegend); CD8 (Dako). The immunostaining procedure followed has been described previously [24]. Briefly, endogenous peroxidases were inhibited using a sodium azide and hydrogen peroxide solution and nonspecific antibody binding was blocked using undiluted culture medium (Sigma; St Louis, Missouri). Mouse antihuman antibodies were applied and incubated overnight at room temperature. After washing with Tris-buffered saline, the biotinylated rabbit anti-mouse secondary antibody (IgG $\mathrm{F}\left[\mathrm{ab}^{\prime}\right]_{2}$; Dako) was applied and incubated for $2 \mathrm{~h}$. After further washing a streptavidin-biotin horseradish peroxidase complex (Vector Laboratories) was added and incubated for $2 \mathrm{~h}$. The sections were then visualized using 3-amino-9ethylcarbazole (AEC) (Vector Laboratories, Land) and counterstained with Mayer's haematoxylin. Positively stained nucleated cells were counted within the submucosa, excluding smooth muscle and glands, and in intact epithelium. Counts were corrected for submucosal area and epithelial length using the program LeicaQWin V3 (Leica Q500IW; Leica, Cambridge, UK). Activated blood vessels were expressed as the ratio of p-selectin and ICAM-1 positive vessels to the pan-endothelial marker EN4-positive vessels.

\section{Flow cytometry}

Flow cytometry was used to analyze lymphocyte subsets in BAL and in the peripheral blood as previously described [61].

\section{Antioxidant analysis}

Reduced glutathione (GSH), oxidized glutathione (GSSG) and total glutathione (GSx) were measured in bronchial wash and BAL fluid returns as described previously [62].

\section{Toxicological analyses in vitro Cell culture}

Mouse macrophage cells (RAW264.7, ATCC, USA) were grown in RPMI 1640 medium supplemented with $10 \%$ heat inactivated fetal bovine serum, $2 \mathrm{mM}$ L-glutamine, and $100 \mathrm{U} \mathrm{mL}^{-1}$ penicillin - streptomycin in a humid atmosphere of $5 \% \mathrm{CO} 2\left(+37^{\circ} \mathrm{C}\right)$. On the day before the experiments, the cell suspension at a concentration of $5 \times 10^{5}$ cells $\mathrm{mL}^{-1}(2 \mathrm{~mL} /$ well $)$ was dispensed into 6 -well plates (total cell count for the well is $1 \times 10^{6}$, Corning Inc., USA). Fresh culture medium $(2 \mathrm{~mL} /$ well $)$ was changed $1 \mathrm{~h}$ before exposure of the cells to particles or their controls.

\section{Cell exposure}

Half an hour before the exposure, emission particles were suspended into DMSO $\left(20 \mu \mathrm{L} \mathrm{mg}^{-1}\right.$, Merck KGaA, Germany). After that, pathogen-free water (W1503, Sigma-Aldrich Corp., USA) was added to gain a PM concentration of $5 \mathrm{mg} \mathrm{mL}^{-1}$. This suspension was sonicated in an ultrasonic water bath (FinnSonic m03, FinnSonic Ltd., Finland) for $30 \mathrm{~min}$ below $+35{ }^{\circ} \mathrm{C}$ to gain homogenous mixture. Mouse RAW264.7 macrophages were exposed for $24 \mathrm{~h}$ to four doses $(15,50,150$, and $300 \mu \mathrm{g} \mathrm{mL}^{-1}$ ) of emission particles from wood log combustion. Exposures of the cells to the particulate samples were made at least in three independent experiments. All in vitro experiments contained diesel PM (dose $150 \mu \mathrm{g} \mathrm{ml}^{-1}$ ) [63] and blank substrate (dose $150 \mu \mathrm{g} \mathrm{ml}^{-1}$ ) controls. Moreover water (dose $1.7 \mathrm{mM}$ ) and DMSO (dose $41.1 \mu \mathrm{M}$ ) served as vehicle controls. Blank sample virtual mass was calculated to be equivalent for PM containing filters average mass.

\section{Toxicological analyses}

After the $24 \mathrm{~h}$ exposure on 6 well plates, the macrophages were scraped from the wells and a sample for MTT-test was taken $(200 \mu \mathrm{l})$. The rest of the cell suspension was centrifuged $\left(6.081 \mathrm{~g},+4{ }^{\circ} \mathrm{C}\right.$, Heraeus Biofuge Fresco, Land) to separate the cells and particles from the cell culture medium. The supernatant was stored at $-80{ }^{\circ} \mathrm{C}$ for the analysis of inflammatory mediators. The cells were suspended into $1 \mathrm{~mL}$ of PBS (Gibco, $\mathrm{UK}$ ), and half of them were used in a propidium iodide exclusion assay, and the other half was fixed with ethanol $\left(70 \% \mathrm{v} / \mathrm{v}\right.$, Altia, Finland) and stored at $+4{ }^{\circ} \mathrm{C}$ for DNA content analysis with flow cytometry (CyAn ADP, Beckman Coulter Inc., USA). The other duplicate part of the cells was used without delay in the Comet assay. 
Inflammatory mediators were also analyzed from those cells culture medium. Moreover, $200 \mu \mathrm{l}$ aliquot of scraped cell suspension was used for MTT test.

\section{Cytotoxicity}

MTT test The mitochondrial activity of the macrophages was analysed with the MTT-test on 96-well plates, which was used for calculating the proportion of the viable cells. The absorbance was detected with the spectrophotometric plate reader and the viability was calculated as a percentage from corresponding readings of the control cells.

Cell cycle analysis The cellular DNA content was analyzed from ethanol fixed cells $(12,000$ cells) by propidium iodide (PI) staining in a flow cytometer (CyAnTM ADP, Beckman Coulter, CA, USA). With this method, cells in the different phases of the cell cycle can be identified. Cells in subG1 phase, which indicates apoptotisis, can be identified as they contain fragmented DNA [64]. In the cell cycle analysis, the fixed cells were treated $0.15 \mathrm{mg} \mathrm{ml}^{-1}$ of ribonuclease A and stained with PI (Sigma Aldrich Corp.) at a final concentration of $8 \mu \mathrm{g} \mathrm{ml}^{-1}$. Etoposide (dose $2 \mu \mathrm{M}$ ) was used as a positive control in cell cycle analyses.

PI exclusion The total amount of PI positive cells was assayed from freshly scraped cells using flow cytometry (CyAnTM ADP, Beckman Coulter, CA, USA). To separate cells and culture medium, the cell suspensions were centrifuged $(370 \times \mathrm{g}, 5 \mathrm{~min})$ and the cell pellet was resuspended in phosphate buffered saline (PBS). Cells were washed once with PBS before staining with PI $(0.5 \mathrm{ml}$ PBS, $1 \mu \mathrm{g} / \mathrm{ml}$ PI) Thereafter, cells were immediately analysed using excitation at $488 \mathrm{~nm}$ and emission filter $613 \pm 20 \mathrm{~nm}$ (channel FL 3). A total of 12,000 cells were analysed for their PI content using Summit software version 4.3 (Beckman Coulter, CA, USA). PI positivity indicated compromised cell membrane.

Genotoxicity DNA damage was detected in the alkaline Single cell gel/Comet assay done in three independent experiments. In the comet assay, DNA strand breaks and breaks associated with incomplete excision repair sites (alkaline labile) can be detected, and therefore the potential genotoxicity of sample can be estimated. The nuclei were analyzed in ethidium bromide-stained cells (100 cells per dose) using an image analysis system (Comet assay IV, Perceptive Instruments Ltd., Suffolk, UK). The Olive tail moment [(tail mean - head mean) $\mathrm{x}$ tail\%DNA/100)] was the parameter used in the statistical analysis. Methyl methanesulfonate (MMS) (dose $15 \mu \mathrm{g} / \mathrm{ml}$ ) and benzo [a] pyrene (dose $240 \mu \mathrm{M}$ ) were used as positive controls in the analyses of genotoxicity.

\section{Cytokine analysis}

Tumor necrosis factor alpha (TNF- $\alpha$ ) and macrophage inflammatory protein-2 (MIP-2) concentrations were analyzed from cell culture medium. Cytokine analysis was made with commercially available enzyme-linked immunosorbent assay (ELISA) kits (R\&D Systems, Minneapolis, MN, USA) according to the manufacturer's instructions. Lipopolysaccharide (dose $0.01 \mu \mathrm{g} / \mathrm{ml}$ ) was used as positive controls in the analyses of cytokines.

\section{Statistics}

Wilcoxon signed-rank test was used for comparison of BW, BAL, flow cytometry and immunohistochemical data. Following confirmation of normality by the Shapiro-Wilk test, paired sample $T$-test was used for lung function and FENO data. Correlations between wood smoke induced effects in BW were analyzed using the Spearman rank order correlation test.

A linear mixed-effect model was used to analyze the impact of wood smoke on systemic inflammatory markers. Subjects were selected as random effect, and exposure, time, order of exposures and interaction between exposure and time as fixed effects. Lung function and FeNO data, which were normally distributed, are presented as mean with $\pm \mathrm{SD}$, and non-normally distributed data as medians with interquartile range.

The measured toxicological responses of PM exposed cells were compared to the blank substrate exposed cells. Levene's test for equality of variances was used for all the samples before analyzing the data with ANOVA. ANOVA and Dunnett's post hoc test was used when results from the MTT-test $(n=6)$ and cytokines $(n=6)$ was analyzed. The results from the OTM analyses, PI-exclusion assay, and cell cycle analyses were analyzed in a nonparametric Mann-Whitney $U$ test $(n=3)$. Differences were considered to be statistically significant at $p<0.05$.

Data were analyzed using SPSS, version 20 for Macintosh $\left(\right.$ IBM $^{\circ}$ SPSS $^{\circ}$ Statistics 20, Chicago, IL, USA) and GraphPad Prism (GraphPad software version 6 for Macintosh, San Diego, CA, USA).

\section{Additional files}

Additional file 1: Table S1. Concentrations ( $\mathrm{ng} / \mathrm{m} 3)$ of specific $\mathrm{PAH}$ compounds in the semi-volatile phase (semi-vol) and particulate phase (PM) of the wood smoke (WS) $(N=10)$ data given as mean with $S D$, and air $(N=2)$ data given as mean. (DOCX $89 \mathrm{~kb})$

Additional file 2: Table S2. Ash forming elements and anions analyzed from the wood log combustion particulate sample with ICP-MSa and ICb. (DOCX $45 \mathrm{~kb}$ )

Additional file 3: Figure S1. Scatterplot of inflammatory cells in the bronchial submucosa after air and wood smoke exposure. (PDF $50 \mathrm{~kb}$ ) Additional file 4: Figure S2. Scatterplot of inflammatory cells in the bronchial epithelium after air and wood smoke exposure. (PDF 49 kb) 
Additional file 5: Figure S3. Scatterplot of inflammatory cells in bronchial wash after air and wood smoke exposure. (PDF $45 \mathrm{~kb}$ )

Additional file 6: Figure S4. Scatterplot of soluble components in bronchial wash after air and wood smoke exposure. (PDF $50 \mathrm{~kb}$ )

Additional file 7: Figure S5. Scatterplot of inflammatory cells in bronchoalveolar lavage after air and wood smoke exposure. (PDF $45 \mathrm{~kb}$ )

Additional file 8: Table S3. Soluble components in the peripheral blood from experimental exposure of 14 healthy subjects to filtered air and wood smoke. Samples were collected before (pre), at $24 \mathrm{~h}$ and $44 \mathrm{~h}$ after exposure, to air and wood smoke. Data are given as medians with interquartile range. (DOCX $62 \mathrm{~kb}$ )

Additional file 9: Table S4. Lung function data from 14 subjects before (pre), immediately after (post) and $24 \mathrm{~h}$ after experimental exposure to filtered air and wood smoke. Data are given as mean with \pm SD. (DOCX $46 \mathrm{~kb})$

Additional file 10: Table S5. FENO data from 14 healthy subjects sampled before (pre), immediately after (post) and $24 \mathrm{~h}$ after experimental exposure to filtered air and wood smoke. Data are given as mean with $\pm S D$. (DOCX $45 \mathrm{~kb}$ )

Additional file 11: Figure S6A. The percentages of mouse RAW264.7 macrophages in the different phases of the cell cycle (SubG1, G1 and S-G2/ M) after exposure to different concentrations $(15,50,150$ and $300 \mu \mathrm{g} \mathrm{ml}-1)$ of emission particles from wood log combustion. Asterisks indicate statistical significance compared to control $(p<0.05)$ analyzed by non-parametric KruskaleWallis test. Figure S6B. The percentages of mouse RAW264.7 macrophages in the different phases of the cell cycle (SubG1, G1 and S-G2/M) after exposure to etoposide and blank substrata. (PDF $154 \mathrm{~kb}$ )

Additional file 12: Figure S7. Inflammation mediators tumor necrosis factor alpha (TNF-a) (A) and macrophage inflammatory protein 2 (MIP-2) (B) concentration in cell culture medium after RAW264.7 macrophages were exposure to four doses $(15,50,150$ and $300 \mu \mathrm{g} \mathrm{ml}-1)$ at $24 \mathrm{~h}$ of cell medium suspended particles emitted from a wood log combustion or lipopolysaccharide (LPS). The asterisks $\left(^{*}\right)$ indicate a statistically significant difference from control cells ( $p<0.05$, Dunnett's test). (PDF $147 \mathrm{~kb}$ )

\section{Abbreviations}

CC16: Club cell protein 16 (formerly called Clara Cell protein 16); CD4: Cluster of differentiation 4; CD8: Cluster of differentiation 8; EC: Elemental carbon; FeNO: Fraction of exhaled nitric oxide; $\mathrm{FEV}_{1}$ : Forced expiratory volume in one second; GOLD: The global initiative for chronic obstructive lung disease; GrzA: Granzyme A; GSH: Reduced glutathione; GSSG: Oxidized glutathione; GSx: Total glutathione; HMGB1: High-mobility group box protein 1; ICAM-1: Intercellular adhesion molecule 1; IL-6: Interleukine-6; IL-8: Interleukine-8; IL-13: Interleukine-13; MIP-2: Macrophage inflammatory protein 2; MMP-9: Matrix MetalloPeptidase-9; MPO: Myeloperoxidase; NF-kB: Nuclear factor-kappa B; NK: Natural killer cells; OC: Organic carbon; $\mathrm{PAH}_{\mathrm{s}}$ : Polycyclic aromatic hydrocarbons; ROS: Reactive oxygen species; RTLF: Respiratory tract lining fluid; SDMA: Symmetric dimethylarginine: SNP: Sodium nitroprusside; TC: Total carbon; TEOM: Tapered elemental oscillating microbalance; TNF-a: Tumor necrosis factor alpha.

\section{Competing interests}

The authors declare that they have no competing interests.

\section{Authors' contributions}

AM took part in study design, was responsible for coordinating the study, led and participated in the clinical study, collecting data, statistical analysis and draft of manuscript. GR, MS and JP took part in study design, performed laboratory analyses, took part in statistical analysis, data interpretation and contributed to the manuscript. JU, JB, ABe and $A B$ took part in study design, participated in carrying out the clinical study, and contributed to the manuscript. RN, EP, CBe, RW and CB took part in study design, were responsible for the generation of the wood smoke exposures and characterization, data collection and interpretation and contributed to the manuscript. PIJ, MSP, OU and MRH designed, performed, analysed and processed the in vitro toxicological data and contributed to the manuscript. ISM took part in study design, performed antioxidant and statistical analysis, interpretation of data and contributed to the manuscript. FJK contributed to the interpretation of the findings and the manuscript. TS took part in the study design, interpretation of data and contributed to the manuscript. All authors read and approved the final manuscript.

\section{Acknowledgements}

The contribution of Annika Johansson, Frida Holmström and Ann-Britt Holmström is acknowledged. The support from the Swedish Energy Agency within the ERA-NET Bioenergy program, the Swedish Heart Lung Foundation, Umeå City Council, Västerbotten County Council (Spjutspets) and Umeå University is acknowledged.

\section{Author details}

${ }^{1}$ Department of Public Health and Clinical Medicine, Division of Medicine/ Respiratory Medicine, Umeå University, Umeå, Sweden. ${ }^{2}$ Department of Applied Physics and Electronics, Thermochemical Energy Conversion Laboratory, Umeå University, Umeå, Sweden. ${ }^{3}$ Department of Environmental Science and Analytical Chemistry, Arrhenius Laboratory, Stockholm University, Stockholm, Sweden. ${ }^{4}$ Department of Environmental Science, University of Eastern Finland, Kuopio, Finland. ${ }^{5}$ Environmental Research Group, MRC-PHE Centre for Environment and Health, King's College London, London, UK.

Received: 15 June 2015 Accepted: 21 October 2015

\section{Published online: 29 October 2015}

\section{References}

1. Langrish JP, Mills NL. Air pollution and mortality in Europe. Lancet. 2014;383(9919):758-60. doi:10.1016/S0140-6736(13)62570-2.

2. Kocbach Bolling A, Pagels J, Yttri KE, Barregard L, Sallsten G, Schwarze PE, et al. Health effects of residential wood smoke particles: the importance of combustion conditions and physicochemical particle properties. Part Fibre Toxicol. 2009;6:29. doi:10.1186/1743-8977-6-29.

3. Jokiniemi J, Hytönen K, Tissari J. Biomass combustion in residential heating: Particulate measurements, sampling, and physicochemical and toxicological characterisation, Final report of the project BiomassPM within the ERA-NET Bioenergy Programme. Kuopio: University of Kuopio; 2008. Report 1/2008.

4. Fullerton DG, Bruce N, Gordon SB. Indoor air pollution from biomass fuel smoke is a major health concern in the developing world. Trans R Soc Trop Med Hyg. 2008;102(9):843-51. doi:10.1016/J.Trstmh.2008.05.028.

5. Lim SS, Vos T, Flaxman AD, Danaei G, Shibuya K, Adair-Rohani H, et al. A comparative risk assessment of burden of disease and injury attributable to 67 risk factors and risk factor clusters in 21 regions, 1990-2010: a systematic analysis for the Global Burden of Disease Study 2010. Lancet. 2012;380(9859):2224-60.

6. Wong GW, Brunekreef B, Ellwood P, Anderson HR, Asher MI, Crane J, et al. Cooking fuels and prevalence of asthma: a global analysis of phase three of the International Study of Asthma and Allergies in Childhood (ISAAC). Lancet Respir Med. 2013;1(5):386-94. doi:10.1016/S2213-2600(13)70073-0.

7. Mishra V. Indoor air pollution from biomass combustion and acute respiratory illness in preschool age children in Zimbabwe. Int J Epidemiol. 2003;32(5):847-53

8. Boman $B C$, Forsberg AB, Jarvholm BG. Adverse health effects from ambient air pollution in relation to residential wood combustion in modern society. Scand J Work Environ Health. 2003:29(4):251-60.

9. Po JY, FitzGerald JM, Carlsten C. Respiratory disease associated with solid biomass fuel exposure in rural women and children: systematic review and meta-analysis. Thorax. 2011;66(3):232-9. doi:10.1136/thx.2010.147884.

10. Hu G, Zhou Y, Tian J, Yao W, Li J, Li B, et al. Risk of COPD from exposure to biomass smoke: a metaanalysis. Chest. 2010;138(1):20-31. doi:10.1378/ chest.08-2114.

11. Kurmi OP, Semple S, Simkhada P, Smith WC, Ayres JG. COPD and chronic bronchitis risk of indoor air pollution from solid fuel: a systematic review and meta-analysis. Thorax. 2010;65(3):221-8. doi:10.1136/thx.2009.124644.

12. Laumbach RJ, Kipen HM. Respiratory health effects of air pollution: update on biomass smoke and traffic pollution. J Allergy Clin Immunol. 2012;129(1):3-11. doi:10.1016/j.jaci.2011.11.021. quiz 2-3.

13. Dherani M, Pope D, Mascarenhas M, Smith KR, Weber M, Bruce N. Indoor air pollution from unprocessed solid fuel use and pneumonia risk in children aged under five years: a systematic review and meta-analysis. Bull World Health Organ. 2008;86(5):390C-8.

14. Barregard L, Sallsten G, Gustafson P, Andersson L, Johansson L, Basu S, et al. Experimental exposure to wood-smoke particles in healthy humans: effects 
on markers of inflammation, coagulation, and lipid peroxidation. Inhal Toxicol. 2006;18(11):845-53. doi:10.1080/08958370600685798.

15. Barregard L, Sallsten G, Andersson L, Almstrand AC, Gustafson P, Andersson $M$, et al. Experimental exposure to wood smoke: effects on airway inflammation and oxidative stress. Occup Environ Med. 2008;65(5):319-24. doi:10.1136/oem.2006.032458

16. Stockfelt L, Sallsten G, Olin AC, Almerud P, Samuelsson L, Johannesson S, et al. Effects on airways of short-term exposure to two kinds of wood smoke in a chamber study of healthy humans. Inhal Toxicol. 2012;24(1):47-59. doi:10.3109/ 08958378.2011 .633281$.

17. Stockfelt L, Sallsten G, Almerud P, Basu S, Barregard L. Short-term chamber exposure to low doses of two kinds of wood smoke does not induce systemic inflammation, coagulation or oxidative stress in healthy humans. Inhal Toxicol. 2013;25(8):417-25. doi:10.3109/08958378.2013.798387.

18. Forchhammer L, Moller P, Riddervold IS, Bonlokke J, Massling A, Sigsgaard T, et al. Controlled human wood smoke exposure: oxidative stress, inflammation and microvascular function. Part Fibre Toxicol. 2012;9:7. doi:10.1186/1743-8977-9-7.

19. Ghio AJ, Soukup JM, Case M, Dailey LA, Richards J, Berntsen J, et al. Exposure to wood smoke particles produces inflammation in healthy volunteers. Occup Environ Med. 2011. doi:10.1136/oem.2011.065276.

20. Sehlstedt M, Dove R, Boman C, Pagels J, Swietlicki E, Londahl J, et al. Antioxidant airway responses following experimental exposure to wood smoke in man. Part Fibre Toxicol. 2010;7:21. doi:10.1186/1743-8977-7-21.

21. Unosson J, Blomberg A, Sandstrom T, Muala A, Boman C, Nystrom R, et al. Exposure to wood smoke increases arterial stiffness and decreases heart rate variability in humans. Part Fibre Toxicol. 2013;10(1):20. doi:10.1186/1743-8977-10-20.

22. Tsuji H, Larson MG, Venditti Jr FJ, Manders ES, Evans JC, Feldman CL, et al. Impact of reduced heart rate variability on risk for cardiac events. The Framingham Heart Study. Circulation. 1996;94(11):2850-5.

23. Adamopoulos D, Vyssoulis G, Karpanou E, Kyvelou SM, Argacha JF, Cokkinos $D$, et al. Environmental determinants of blood pressure, arterial stiffness, and central hemodynamics. J Hypertens. 2010;28(5):903-9.

24. Salvi S, Blomberg A, Rudell B, Kelly F, Sandstrom T, Holgate ST, et al. Acute inflammatory responses in the airways and peripheral blood after short-term exposure to diesel exhaust in healthy human volunteers. Am J Respir Crit Care Med. 1999;159(3):702-9.

25. Pourazar J, Frew AJ, Blomberg A, Helleday R, Kelly FJ, Wilson S, et al. Diesel exhaust exposure enhances the expression of IL-13 in the bronchial epithelium of healthy subjects. Respir Med. 2004;98(9):821-5.

26. Pourazar J, Mudway IS, Samet JM, Helleday R, Blomberg A, Wilson SJ, et al. Diesel exhaust activates redox-sensitive transcription factors and kinases in human airways. Am J Physiol Lung Cell Mol Physiol. 2005;289(5):L724-30. doi:10.1152/ajplung.00055.2005.

27. Londahl J, Pagels J, Boman C, Swietlicki E, Massling A, Rissler J, et al. Deposition of biomass combustion aerosol particles in the human respiratory tract. Inhal Toxicol. 2008;20(10):923-33. doi:10.1080/08958370802087124.

28. Lamberg $H$, Nuutinen $K$, Tissari J, Ruusunen J, Yli-Pirila P, Sippula O, et al. Physicochemical characterization of fine particles from small-scale wood combustion. Atmos Environ. 2011:45(40):7635-43. doi:10.1016/ J.Atmosenv.2011.02.072.

29. Sadiktsis I, Koegler JH, Benham T, Bergvall C, Westerholm R. Particulate associated polycyclic aromatic hydrocarbon exhaust emissions from a portable power generator fueled with three different fuels - A comparison between petroleum diesel and two biodiesels. Fuel. 2014;115:573-80. doi:10.1016/J.Fuel.2013.07.062

30. Nordenhall C, Pourazar J, Blomberg A, Levin JO, Sandstrom T, Adelroth E. Airway inflammation following exposure to diesel exhaust: a study of time kinetics using induced sputum. Eur Respir J. 2000;15(6):1046-51.

31. Rudell B, Blomberg A, Helleday R, Ledin MC, Lundback B, Stjernberg N, et al. Bronchoalveolar inflammation after exposure to diesel exhaust: comparison between unfiltered and particle trap filtered exhaust. Occup Environ Med. 1999;56(8):527-34.

32. Bosson J, Pourazar J, Forsberg B, Adelroth E, Sandstrom T, Blomberg A. Ozone enhances the airway inflammation initiated by diesel exhaust. Respir Med. 2007;101(6):1140-6. doi:10.1016/j.rmed.2006.11.010.

33. Edwards D. Immunological effects of tobacco smoking in "healthy" smokers. COPD. 2009;6(1):48-58. doi:10.1080/15412550902724206.

34. Bhatta N, Dhakal SS, Rizal S, Kralingen KW, Niessen L. Clinical spectrum of patients presenting with bronchiectasis in Nepal: evidence of linkage between tuberculosis, tobacco smoking and toxic exposure to biomass smoke. Kathmandu Univ Med J. 2008;6(2):195-203.

35. Mishra VK, Retherford RD, Smith KR. Cooking with biomass fuels increases the risk of tuberculosis. Natl Fam Health Surv Bull. 1999;13:1-4.

36. Smith KR, McCracken JP, Weber MW, Hubbard A, Jenny A, Thompson LM, et al. Effect of reduction in household air pollution on childhood pneumonia in Guatemala (RESPIRE): a randomised controlled trial. Lancet. 2011;378(9804):1717-26. doi:10.1016/S0140-6736(11)60921-5.

37. Tapanainen M, Jalava PI, Maki-Paakkanen J, Hakulinen P, Lamberg H, Ruusunen J, et al. Efficiency of log wood combustion affects the toxicological and chemical properties of emission particles. Inhal Toxicol. 2012;24(6):343-55. doi:10.3109/08958378.2012.671858.

38. Jalava PI, Aakko-Saksa P, Murtonen T, Happo MS, Markkanen A, Yli-Pirila P, et al. Toxicological properties of emission particles from heavy duty engines powered by conventional and bio-based diesel fuels and compressed natural gas. Part Fibre Toxicol. 2012;9(1):37. doi:10.1186/1743-8977-9-37

39. Uski O, Jalava PI, Happo MS, Leskinen J, Sippula O, Tissari J, et al. Different toxic mechanisms are activated by emission PM depending on combustion efficiency. Atmos Environ. 2014;89(0):623-32. http://dx.doi.org/10.1016/ j.atmosenv.2014.02.036.

40. Bolling AK, Totlandsdal Al, Sallsten G, Braun A, Westerholm R, Bergvall C, et al. Wood smoke particles from different combustion phases induce similar pro-inflammatory effects in a co-culture of monocyte and pneumocyte cell lines. Part Fibre Toxicol. 2012;9(1):45. doi:10.1186/1743-8977-9-45.

41. Happo MS, Uski O, Jalava PI, Kelz J, Brunner T, Hakulinen P, et al. Pulmonary inflammation and tissue damage in the mouse lung after exposure to PM samples from biomass heating appliances of old and modern technologies. Sci Total Environ. 2012;443C:256-66. doi:10.1016/j.scitotenv.2012.11.004.

42. Uski OJ, Happo MS, Jalava PI, Brunner T, Kelz J, Obernberger I, et al. Acute systemic and lung inflammation in C57BI/6 J mice after intratracheal aspiration of particulate matter from small-scale biomass combustion appliances based on old and modern technologies. Inhal Toxicol. 2012;24(14):952-65. doi:10.3109/08958378.2012.742172.

43. Danielsen $\mathrm{PH}$, Moller $\mathrm{P}$, Jensen $\mathrm{KA}$, Sharma AK, Wallin $H$, Bossi $R$, et al. Oxidative stress, DNA damage, and inflammation induced by ambient air and wood smoke particulate matter in human A549 and THP-1 cell lines. Chem Res Toxicol. 2011;24(2):168-84. doi:10.1021/tx100407m.

44. Jalava PI, Happo MS, Kelz J, Brunner T, Hakulinen P, Maki-Paakkanen J, et al. In vitro toxicological characterization of particulate emissions from residential biomass heating systems based on old and new technologies. Atmos Environ. 2012;50:24-35. doi:10.1016/J.Atmosenv.2012.01.009.

45. Corsini E, Budello S, Marabini L, Galbiati V, Piazzalunga A, Barbieri P, et al. Comparison of wood smoke PM2.5 obtained from the combustion of FIR and beech pellets on inflammation and DNA damage in A549 and THP-1 human cell lines. Arch Toxicol. 2013;87(12):2187-99. doi:10.1007/s00204-013-1071-z.

46. O'Shaughnessy TC, Ansari TW, Barnes NC, Jeffery PK. Inflammation in bronchial biopsies of subjects with chronic bronchitis: inverse relationship of CD8+ T lymphocytes with FEV1. Am J Respir Crit Care Med. 1997;155(3):852-7. doi:10.1164/ajrccm.155.3.9117016.

47. Stenfors N, Bosson J, Helleday R, Behndig AF, Pourazar J, Tornqvist H, et al. Ozone exposure enhances mast-cell inflammation in asthmatic airways despite inhaled corticosteroid therapy. Inhal Toxicol. 2010;22(2):133-9. doi:10.3109/08958370903005736.

48. Behndig AF, Mudway IS, Brown JL, Stenfors N, Helleday R, Duggan ST, et al. Airway antioxidant and inflammatory responses to diesel exhaust exposure in healthy humans. Eur Respir J. 2006;27(2):359-65. doi:10.1183/ 09031936.06.00136904

49. Blomberg A, Mudway IS, Nordenhall C, Hedenstrom H, Kelly FJ, Frew AJ et al. Ozone-induced lung function decrements do not correlate with early airway inflammatory or antioxidant responses. Eur Respir J. 1999;13(6):1418-28.

50. Salvi SS, Nordenhall C, Blomberg A, Rudell B, Pourazar J, Kelly FJ, et al. Acute exposure to diesel exhaust increases IL-8 and GRO-alpha production in healthy human airways. Am J Respir Crit Care Med. 2000;161(2 Pt 1):550-7.

51. Sandstrom T, Stjernberg N, Andersson MC, Kolmodin-Hedman B, Lindstrom $\mathrm{K}$, Rosenhall $\mathrm{L}$. Cell response in bronchoalveolar lavage fluid after sulfur dioxide exposure. Scand J Work Environ Health. 1989;15(2):142-6.

52. Sandstrom T, Stjernberg N, Eklund A, Ledin MC, Bjermer L, Kolmodin-Hedman $B$, et al. Inflammatory cell response in bronchoalveolar lavage fluid after nitrogen dioxide exposure of healthy subjects: a dose-response study. Eur Respir J. 1991;4(3):332-9. 
53. Moiseeva EP, Bradding P. Mast cells in lung inflammation. Adv Exp Med Biol. 2011;716:235-69. doi:10.1007/978-1-4419-9533-9_13.

54. Reber LL, Daubeuf F, Pejler G, Abrink M, Frossard N. Mast cells contribute to bleomycin-induced lung inflammation and injury in mice through a chymase/mast cell protease 4-dependent mechanism. J Immunol. 2014;192(4):1847-54. doi:10.4049/jimmunol.1300875.

55. O'Neill MS, Diez-Roux AV, Auchincloss AH, Shen M, Lima JA, Polak JF, et al. Long-term exposure to airborne particles and arterial stiffness: the Multi-Ethnic Study of Atherosclerosis (MESA). Environ Health Perspect. 2011;119(6):844-51. doi:10.1289/ehp.0901524.

56. Kleiger RE, Miller JP, Bigger Jr JT, Moss AJ. Decreased heart rate variability and its association with increased mortality after acute myocardial infarction. Am J Cardiol. 1987;59(4):256-62.

57. Dutta A, Bhattacharya P, Lahiri T, Ray MR. Immune cells and cardiovascular health in premenopausal women of rural India chronically exposed to biomass smoke during daily household cooking. Sci Total Environ. 2012:438:293-8. doi:10.1016/j.scitotenv.2012.08.065.

58. Guarnieri MJ, Diaz JV, Basu C, Diaz A, Pope D, Smith KR, et al. Effects of woodsmoke exposure on airway inflammation in rural Guatemalan women. PLoS One. 2014;9(3):e88455. doi:10.1371/journal.pone.0088455.

59. Rudell B, Ledin MC, Hammarstrom U, Stjernberg N, Lundback B, Sandstrom T. Effects on symptoms and lung function in humans experimentally exposed to diesel exhaust. Occup Environ Med. 1996;53(10):658-62.

60. Standardization of Spirometry, 1994 Update. American Thoracic Society. Am J Respir Crit Care Med. 1995;152(3):1107-36.

61. Roos-Engstrand E, Pourazar J, Behndig AF, Bucht A, Blomberg A. Expansion of CD4 + CD25+ helper T cells without regulatory function in smoking and COPD. Respir Res. 2011;12:74. doi:10.1186/1465-9921-12-74.

62. Mudway IS, Stenfors N, Blomberg A, Helleday R, Dunster C, Marklund SL, et al. Differences in basal airway antioxidant concentrations are not predictive of individual responsiveness to ozone: a comparison of healthy and mild asthmatic subjects. Free Radic Biol Med. 2001;31(8):962-74.

63. Ruusunen J, Tapanainen M, Sippula O, Jalava PI, Lamberg H, Nuutinen K, et al. A novel particle sampling system for physico-chemical and toxicological characterization of emissions. Anal Bioanal Chem. 2011;401(10):3183-95. doi:10.1007/s00216-011-5424-2.

64. Darzynkiewicz Z, Bruno S, Del Bino G, Gorczyca W, Hotz MA, Lassota P, et al. Features of apoptotic cells measured by flow cytometry. Cytometry. 1992;13(8):795-808. doi:10.1002/cyto.990130802.

\section{Submit your next manuscript to BioMed Central and take full advantage of:}

- Convenient online submission

- Thorough peer review

- No space constraints or color figure charges

- Immediate publication on acceptance

- Inclusion in PubMed, CAS, Scopus and Google Scholar

- Research which is freely available for redistribution

Submit your manuscript at www.biomedcentral.com/submit 